ELWIRA WARDA* - LUBLIN

\title{
SZKAPLERZ ZAKONNY
}

Szkaplerz zakonny (łac. scapulare - okrycie pleców) posiada kilka znaczeń: 1. nazwa części ubioru niektórych zakonów, np. karmelitów, szata bez rękawów nakładana na habit, składająca się z dwóch prostokątnych kawałków materiału i otworu na głowę lub kaptura (na wschodzie zwany analobo), przykrywająca ramiona i opadająca aż do stóp. 2. nazwa przedmiotu dewocyjnego składającego się z dwóch małych kawałków poświęconego materiału połączonych tasiemką, noszonego na piersi i na plecach; używany najczęściej przez członków bractw kościelnych. 3. medalik szkaplerzny z odpowiednim wizerunkiem (na jednej stronie obraz Najświętszego Serca, a na odwrocie Najświętszej Dziewicy). Szkaplerz sukienny i medalik szkaplerzny mają taką samą wartość duchową, chociaż przyjęcie do Bractwa Szkaplerznego musi dokonać się przy pomocy szkaplerza sukiennego, który później można zastąpić noszonym na szyi medalikiem. Ze względów praktycznych zezwolił na to papież św. Pius X w $1910 \mathrm{r}$.

W VI wieku św. Benedykt ${ }^{1}$ wprowadził fartuch chroniący habit na czas pracy fizycznej (scapolare propter opera). Szkaplerz ten, zwany „wielkim” funkcję ochronną pełnił do XIII wieku. Od połowy tegoż stulecia osoby świeckie zaczęły nosić tzw. mały szkaplerz jako symbol i nową formę pobożności w Kościele. Szkaplerz zapoczątkował św. Szymon Stock, generał karmelitów, któremu w nocy z 15 na 16 czerwca 1251 roku objawiła się NMP wypowiadająca słowa:

Weź, mój synu, ten szkaplerz twego Zakonu, jako znak szczególniejszej łaski mojej. Kto umrze odziany szkaplerzem, uniknie ognia piekielnego. Jest on znakiem zbawienia, obroną w niebezpieczeństwach, zakładem pokoju i wiecznej szczęśliwości ${ }^{2}$

* Elwira Warda - mgr filozofii, starszy bibliotekarz w Bibliotece Uniwersyteckiej KUL, e-mail: warda@kul.lublin.pl.

${ }^{1}$ Benedykt z Nursji (ok. 480-547) - ojciec monastycyzmu zachodniego, który w roku 529 założył klasztor na Monte Cassino, autor reguły benedyktyńskiej. Oryginał napisanej przez niego Reguły spłonął w 896 roku w czasie pożaru klasztoru w Teano. Dewiza św. Benedykta to Ora et labora (łac. módl się i pracuj), a hasłem przewodnim reguły zakonu benedyktynów Ordo et pax (Ład i pokój).

${ }^{2}$ Józef Krosiński, Piękność obrzędów Kościoła Katolickiego, Tarnów 1905. 
Znakiem duchowej przynależności do bractwa i rodziny zakonnej stało się nałożenie szkaplerza przypisanego danemu zakonowi. $Z$ upływem czasu szkaplerz przybrał postać dwóch niewielkich, prostokątnych kawałków wełnianego materiału o określonej barwie połączonych dwoma sznurkami lub tasiemkami. Taki szkaplerz, nakładany przez głowę, nosi się na lub pod ubraniem. Wolno go zdobić obrazem tkanym, haftowanym lub też naszytym. Obraz ów może być z innego materiału i innej barwy niż sam szkaplerz, a rozmiary ozdób dostosowane są do jego wielkości. Najczęściej umieszczano obrazki związane z pochodzeniem szkaplerza, co nierzadko było wynikiem objawień. Obecnie niektóre szkaplerze są tylko jednym prostokątnym kawałkiem sukna z umieszczonymi po obu jego stronach właściwymi obrazkami. Najczęściej szkaplerze pozostały związane z zakonami lub zgromadzeniami zakonnymi. Dlatego też uprawnienia do ich poświęcania oraz nakładania posiadają jedynie członkowie tych zgromadzeń, natomiast pozostałe mogą poświęcać i nakładać wszyscy duchowni. Określają to szczegółowe przepisy. Noszenie szkaplerza pozwala uzyskiwać odpusty nadane bractwu z woli Kościoła.

Poniżej zestawiono zakony męskie i żeńskie oraz opisano ich habity, którym przypisany jest właściwy szkaplerz wielki.

\section{Zakony męskie}

Benedyktyni - Zakon św. Benedykta ${ }^{3}$ (Ordo Sancti Benedicti, OSB); czarna tunika przepasana skórzanym pasem, na wierzchu czarny szkaplerz z kapturem; do chóru czarna tzw. kukulla ${ }^{4}$ dla profesów wieczystych, czarna kapa dla profesów czasowych i nowicjuszy.

Bonifratrzy - Zakon Szpitalny Świętego Jana Bożego ${ }^{5}$ (Ordo Hospitalarius Sancti Joannis de Deo, $\mathrm{OH}$ ); czarna tunika przepasana czarnym skórzanym pasem, na habicie czarny długi szkaplerz; w pracy używany habit koloru białego.

Cystersi - Zakon Cystersów ${ }^{6}$ (Ordo Cisterciensis, OCist); biały habit z czarnym szkaplerzem, przepasany czarnym płóciennym pasem; do chóru biała kukulla.

Dominikanie - Zakon Braci Kaznodziejów ${ }^{7}$ (Ordo Fratrum Praedicatorium,

${ }^{3}$ Najstarszy zakon założony na Zachodzie Europy w 529 roku przez Benedykta z Nursji, który opracował pierwszą regułę zakonną. Postawa benedyktyńska wyraża się w dewizie: Ora et labora (Módl się i pracuj). W Polsce działają od końca X wieku. Na początku wieku XI prowadzili działalność misyjną, a w połowie stulecia osiedlili się w Tyńcu.

${ }^{4}$ Szeroka suknia z rękawami.

${ }^{5}$ Zakon oparty na regule św. Augustyna założony przez Jana Bożego w Granadzie w 1540 roku, w celu opieki nad chorymi. W 1572 roku zatwierdzony został przez papieża Piusa V. Do Polski bonifratrzy przybyli w 1609 roku.

${ }^{6}$ Zakon założony przez Roberta z Molesme w 1098 roku w wyniku reformy zakonu benedyktyńskiego. Cystersi żyją zgodnie z benedyktyńska dewizą: Ora et labora. Jest to zakon klauzurowy, stawiający przede wszystkim na modlitwę. Zakonnicy utrzymują się z pracy na roli i działalności rzemieślniczej. Do Polski przybyli około 1140 roku.

${ }^{7}$ Św. Dominik (Domenigo Guzman - ok. 1170-1221) założył Zakon Kaznodziejski, który został zatwierdzony przez papieża w 1216 roku. Wyznając zasadę ewangelicznego ubóstwa dominikanie stali się jednym z zakonów żebrzących. Do Polski przybyli w roku 1222. 
OP); biała tunika ze szkaplerzem i kapturem, przepasana skórzanym pasem z różańcem; na biały habit nakładana czarna kapa z czarnym kapturem.

Kameduli - Kongregacja Eremitów Kamedułów Góry Koronnej ${ }^{8}$ (Congregatio Eremitarum Camaldulensium Montis Coronae, ECMC); biała tunika dochodząca do kostek, na niej biały szkaplerz z kapturem monastycznym, nieco krótszy od tuniki, płócienny biały pas; na nich jeszcze krótszy biały płaszcz chórowy.

Kapucyni Tercjarze - Zgromadzenie Tercjarzy Kapucynów Naszej Matki Bolesnej; brązowy habit ze szkaplerzem i kapturem, jako pas biały sznur z trzema węzłami.

Karmelici - Zakon Braci Najświętszej Maryi Panny z Góry Karmelu9 (Ordo Fratrum Beatae Mariae Virginis de Monte Carmelo, OCarm); tunika koloru ciemnobrązowego oraz szkaplerz i kaptur tego samego koloru; tunika przepasana skórzanym pasem; z okazji uroczystości biały płaszcz, krótszy od tuniki oraz biały kaptur.

Karmelici Bosi - Zakon Braci Bosych Najświętszej Maryi Panny z Góry Karmel; habit koloru brązowego - tunika z pasem, szkaplerzem i kapturem; w pewnych okolicznościach także płaszcz i kaptur koloru białego; od stroju karmelitów trzewiczkowych różni się nieco mniejszym kapturem.

Kartuzi - Zakon Kartuzów ${ }^{10}$ (Ordo Carthusiensis, Ocart.); biały habit z szerokim szkaplerzem (nazywany przez kartuzów kukullą), którego przód i tył połączone są dwoma paskami materiału, które stanowią znak ślubów zakonnych. W czasie liturgii nowicjusze noszą czarny długi płaszcz z kapturem.

Mercedarianie - Zakon Najświętszej Maryi Panny Miłosierdzia; biały habit $\mathrm{z}$ białym szkaplerzem i kapturem.

Paulini - Zakon Świętego Pawła Pierwszego Pustelnika ${ }^{11}$ (Ordo Fratrum Sancti Pauli Primi Eremitae, OSPPE); biała tunika przepasana białym parcianym pasem z cząstką różańca, na tunice biały szkaplerz i biały kaptur; na głowie biała piuska; po ślubach wieczystych w czasie uroczystej liturgii biały płaszcz procesyjny z kapturem.

Pocieszyciele - Zgromadzenie Braci Pocieszycieli z Getsemani ${ }^{12}$ (Congregatio Fratrum Consolatorum de Getsemani, (CCG); czarny habit z wszytym z przodu szkaplerzem, przepasany skórzanym czarnym pasem, przy pasie różaniec złożony z pięciu dziesiątków, na piersi pektorał, na szyi koloratka; po ślubach wieczystych do liturgii i adoracji biały kaptur i biały płaszcz.

\footnotetext{
${ }^{8}$ Zakon oparty na regule benedyktyńskiej został założony w 1012 roku przez św. Romualda z Rawenny. Kameduli mieszkają w pustelniach (eremach).

${ }^{9}$ Zakon żebrzący. Do Polski zostali sprowadzeni w 1396 roku przez Jadwigę Andegaweńską i Władysława II Jagiełłę. Osiedlili się w Krakowie.

${ }^{10}$ Zakon o surowej regule założony przez Brunona z Kolonii w 1084 roku został zatwierdzony w roku 1176. W Polsce kartuzi są obecni od XIII wieku.

${ }^{11}$ Zakon Paulinów powstał na Węgrzech w wieku XIII, a zatwierdzony został przez legata papieża Klemensa V 13 grudnia 1308 roku. Założył go Euzebiusz z Ostrzyhomia. Do Polski paulini przybyli w roku 1382 i osiedlili się na Jasnej Górze w Częstochowie.

${ }^{12}$ Zakon powstał w Czechach w 1922 roku i został zatwierdzony przez papieża Piusa XI.
} 
Sercanie Biali - Zgromadzenie Najświętszych Serc Jezusa i Maryi oraz Wieczystej Adoracji Najświętszego Sakramentu Ołtarza ${ }^{13}$ (Congregatio Sacrorum Cordium Iesu et Mariae necnon adorationis perpetuae Sanctissimi Sacramenti altaris, SSCC); biały habit, przepasany skórzanym paskiem koloru naturalnego, na habicie biały szkaplerz; na szkaplerzu wyhaftowane dwa złączone Serca Jezusa i Maryi, wokół serc potrójne lub podwójne splecione ciernie, tworzące jakby kolistą obręcz.

Trynitarze - Zakon Trójcy Przenajświętszej ${ }^{14}$; biały habit przepasany czarnym skórzanym paskiem, na habicie biały szkaplerz z czerwono - niebieskim krzyżem oraz biały kaptur.

Serwici - Zakon Sług Maryi ${ }^{15}$ (Ordo Servorum Mariae); czarny habit przepasany skórzanym paskiem oraz czarny szkaplerz.

\section{Zakony żeńskie}

Albertynki - Zgromadzenie Sióstr Albertynek Posługującym Ubogim ${ }^{16}$ (Congregatio Sororum Albertinarum Pauperibus Inservientium, CSAPI); habit, szkaplerz i welon z ciemnoszarego materiału; pod welonem, na głowie biały płócienny welonik; habit przepasany sznurem z pięcioma węzłami, przy boku różaniec $\mathrm{z}$ grubych brązowych ziaren $\mathrm{z}$ medalikiem; u profesek wieczystych na piersi krzyżyk z pasyjką średniej wielkości.

Augustianki - Zgromadzenie Sióstr Świętego Augustyna w Polsce ${ }^{17}$ (Ordo Sancti Augustini, OSA); czarny habit, przepasany czarnym skórzanym paskiem, na habicie czarny szkaplerz, kornet z dzianiny z czarnym welonem.

Benedyktynki - Mniszki Zakonu Świętego Benedykta (Ordo Monialim Sancti Benedicti, OSB) ${ }^{18}$; habit - czarna tunika i szkaplerz; skórzany pas, białe zawicie, czarny welon; do chóru płaszcz z szerokimi rękawami.

Benedyktynki Misjonarki - Zgromadzenie Sióstr Benedyktynek Misjonarek ${ }^{19}$; czarny habit, przepasany czarnym skórzanym paskiem, na habicie czarny szkaplerz, welon czarny biało podszyty, krzyż zawieszony na czarnej tasiemce.

${ }^{13}$ Zakon założony przez Józefa Courdin we Francji w 1800 roku został zatwierdzony w roku 1817. W Polsce sercanie biali pojawili się w 1947 roku.

${ }^{14}$ Dawniej Zakon Świętej Trójcy od Wykupu Niewolników założony w 1193 roku przez Jana z Mathy i Feliksa de Valois. Został zatwierdzony przez papieża Innocentego III bullą Operante divine dispositionis w 1198 roku.

${ }^{15}$ Zgromadzenie zakonne założone w 1233 roku we Włoszech, którego celem było rozważanie boleści Maryi i naśladowanie jej cnót.

${ }^{16}$ Zgromadzenie Sióstr Trzeciego Zakonu Św. Franciszka Posługujące Ubogim założył 15 stycznia 1891 roku św. Adam Chmielowski (Brat Albert).

${ }^{17}$ Zgromadzenie założył w 1583 roku w Krakowie Szymon Mniszek, kaznodzieja Stefana Batorego. Augustianki zajmują się pracą charytatywną i wychowawczą.

18 Żeńska gałąź benedyktynów pojawiła się w VII wieku. Założycielką zakonu była św. Scholastyka - bliźniacza siostra św. Benedykta. Do Polski benedyktynki przybyły w wieku XII.

${ }^{19}$ Misyjne i apostolskie zgromadzenie zakonne zostało założone w 1917 roku przez Jadwigę Józefę Kuleszę. 
Bernardynki - Mniszki Trzeciego Zakonu Regularnego św. Franciszka z Asyżu ${ }^{20}$; brązowy habit długi do kostek, przepasany białym sznurem z trzema węzłami na dłuższym końcu, długie rękawy o nie większej niż $50 \mathrm{~cm}$ szerokości; szkaplerz tego samego koloru, krótszy od habitu o około $5 \mathrm{~cm}$, z wycięciem przy szyi $8 \times 18 \mathrm{~cm}$; czarny welon $95 \times 140 \mathrm{~cm}$, upięty na białym czepku, z przepaską na czole zwaną bindalem; srebrny pierścionek $\mathrm{z}$ wizerunkiem Ukrzyżowanego, który może być umieszczony na sercu.

Brygidki - Zakon Najświętszego Zbawiciela Świętej Brygidy (Ordo Sanctissimi Salvatoris Sanctae Brigittae, O.SS.S.) ${ }^{21}$; szary habit z szarym szkaplerzem i białym wykończeniem, na głowie czarny welon z białą koroną w kształcie krzyża z pięcioma czerwonymi znakami.

Dominikanki - Zgromadzenie Sióstr św. Dominika (Sorores Ordinis Sancti Dominici in Polonia, OP ${ }^{22}$; biały habit przepasany skórzanym paskiem z całym różańcem (15 tajemnic), biały szkaplerz i pelerynka, czarny płaszcz tzw. kapa, czarny welon.

Franciszkanki - Zgromadzenie Sióstr Franciszkanek Maryi Nieustającej Pomocy ${ }^{23}$; długi czarny habit ze szkaplerzem, przepasany białym sznurem, u lewego boku koronka franciszkańska, czarny, długi welon upięty na białym czepku zakrywającym $3 / 4$ czoła i część twarzy, na piesi krzyżyk.

Franciszkanki Służebnice Krzyża - Siostry Franciszkanki Służebnice Krzyża zwane siostrami z Lasek ${ }^{24}$; brązowy habit przepasany sznurem $\mathrm{z}$ drewnianym różańcem, na habicie brązowy szkaplerz, na głowie brązowy welon z białą wypustką, poza tym biała stójka (golf); na misjach na piersi krzyżyk, w Indiach habit i welon w kolorze kawowym.

Franciszkanki Szpitalne - Zgromadzenie Sióstr Pielęgniarek Trzeciej Reguły św. Franciszka ${ }^{25}$; czarny habit przepasany białym sznurem z trzema węzłami i zawieszony na nim różaniec, na habicie czarny szkaplerz, na którym znajduje się franciszkański znak zgromadzenia - Tau.

Siostry Jezusa Miłosiernego - Zgromadzenie Sióstr Jezusa Miłosiernego; czarny habit przepasany paskiem, szkaplerz i welon.

Kamedułki - Mniszki Kamedułki (Monasterium Monialium Camaldulensium, O.Cam lub OSB Cam.) ${ }^{26}$; biały habit z szerokimi, wywijanymi rękawami,

${ }^{20}$ Zakon założył św. Jan Kapistran w 1454 roku. Zakon istnieje tylko w Polsce.

${ }^{21}$ Zakon - oparty na regule św. Augustyna - został utworzony około 1346 roku w Szwecji przez św. Brygidę w celu szerzenia kultu Matki Bożej. Do Polski brygidki przybyły w 1396 roku.

${ }^{22}$ Zgromadzenie zakonne zostało założone przez Różę Kolumbę Białecką w 1861 roku. Patronami zakonu są Matka Boża i św. Józef.

${ }^{23}$ Franciszkanki Maryi lub Zgromadzenie Sióstr Franciszkanek Matki Bożej Nieustającej Pomocy. Zgromadzenie założyła Anna Bruner w Budapeszcie w 1932 roku .

${ }^{24}$ Zgromadzenie zakonne założone w 1918 roku przez Różę Czacką. Jego głównym celem jest służba niewidomym. W 1922 roku powstało Dzieło Niewidomych w Laskach, gdzie mieści się dom macierzysty zgromadzenia.

${ }^{25}$ Zgromadzenie założył w 1844 roku w Westfalii o. Krzysztof Bersmeyer. Siostry prowadzą działalność charytatywna i apostolską.

${ }^{26}$ Zakon kontemplacyjny został założony w XI wieku przez św. Romualda z Rawenny. Klasztor polskich kamedułek mieści się w Złoczewie k. Sieradza. 
przepasany dość szerokim, długim wiązanym z prawej strony paskiem; szkaplerz na wierzchu, krzyż ukryty pod szkaplerzem; czarny welon, opięty nisko na czole; do chóru używany biały wełniany płaszcz; do wychodzenia na zewnątrz zabudowań - czarny płaszcz.

Kapucynki - Mniszki Klaryski Kapucynki (Moniales Clarisae Cappucinae lub Ordo Sanctae Clarae Capuccinarum, OSCCap) ${ }^{27}$; brązowy habit, przepasany białym sznurem z trzema węzłami; z lewej strony przy pasie franciszkańska koronka, na habicie szkaplerz, na szyi na tasiemce drewniany krzyżyk z metalową pasyjką; na głowie czarny welon, pod którym białe ubranko i bindka ${ }^{28}$; poza tym płaszcz koloru brązowego w kształcie peleryny.

Karmelitanki Bose - Mniszki Bose Zakonu Najświętszej Maryi Panny z Góry Karmelu ${ }^{29}$; brązowy habit aż do stóp, z szerokimi rękawami i przepasany skórzanym pasem, na habicie szkaplerz na białej toce, na głowie czarny welon (biały dla nowicjuszek i profesek czasowych); w określonych okolicznościach, np. msza św., uroczysta Liturgia Godzin, na habit nakładany biały płaszcz; całości stroju dopełnia duży drewniany różaniec za pasem z lewego boku i krzyżyk z pasyjką, noszony na sercu.

Klaryski - Zakon świętej Klary (Ordo Sanctae Clarae, OSC) ${ }^{30}$; czarna tunika w kształcie krzyża, na niej szkaplerz z prostokątnym wycięciem, na głowie welon z czarnej tkaniny, białe zawicie, na które składa się kapik ${ }^{31}$ i bindal; poza tym biały pasek do przepasania, koronka franciszkańska oraz płaszcz.

Loretanki - Zgromadzenie Sióstr Matki Bożej Loretańskiej Reguły św. Benedykta ${ }^{32}$; czarny habit $\mathrm{z}$ białym kołnierzykiem, przepasany czarnym skórzanym paskiem, na habicie czarny szkaplerz, na głowie czarny welon z białym krzyżykiem nad czołem, upięty na białym tzw. czółku, pod którym biały czepek, na piersi krzyżyk z wizerunkiem Chrystusa na czarnej tasiemce.

Pasterki - Zgromadzenie Sióstr Pasterek od Opatrzności Bożej33; czarny habit, przepasany paskiem, na habicie czarny szkaplerz, długi jak habit, i biały kołnierzyk, na głowie biały płócienny czepek zakrywający włosy oraz upięty na nim czarny welon, na szkaplerzu krzyżyk, a u boku z lewej strony czarny różaniec.

Pijarki - Instytut Córek Maryi Sióstr Szkół Pobożnych; średniej długości habit (30 cm nad ziemią) koloru popielatego, przepasany płóciennym, krótkim pa-

${ }^{27}$ Mniszki Klaryski Kapucynki lub Zakon Kapucynek św. Klary założyła Maria Lorenza Longo w 1538 roku w Neapolu we Włoszech. To zakon kontemplacyjny, habitowy.

${ }^{28}$ Binda, bindka, bindal - dawniej kobieca przepaska na czoło lub szyję.

${ }^{29}$ Żeński zakon kontemplacyjny o ścisłej klauzurze powstał w 1463 roku z inicjatywy generała zakonu karmelitów o. Jana Soretha. Za sprawą św. Teresy z Awili został zreformowany w roku 1562.

${ }^{30}$ Zakon kontemplacyjny założony w 1212 roku przez św. Klarę. Do Polski został sprowadzony przez córkę Leszka Białego bł. Salomeę. Siostry zamieszkały w Zawichoście, później w Skale, a do Krakowa przeniosły się w roku 1316.

${ }^{31}$ Kapik, kapa - kobiece nakrycie głowy. W dawnej Polsce nazwa ta obejmowała wszelkie czepki.

${ }^{32}$ Zgromadzenie założył w 1920 roku ks. Ignacy Kłopotowski.

${ }^{33}$ Zgromadzenie zostało założone w Poznaniu w roku 1894 przez Marię Karłowską. Głównym celem jest praca wychowawcza wśród dziewcząt i opieka nad samotnymi matkami. 
sem zakończonym frędzlami; na habicie popielaty szkaplerz, mający symetrycznie rozmieszczone na ramionach i na pasie płócienne guziki; na głowie popielaty welon.

Serafitki - Zgromadzenie Córek Matki Bożej Bolesnej3 ${ }^{34}$; brązowy habit, przepasany białym sznurem, na habicie brązowy szkaplerz.

Sercanki - Zgromadzenie Służebnic Najświętszego Serca Jezusa ${ }^{35}$; czarny habit, przepasany białym franciszkańskim sznurem; na habicie czarny szkaplerz z wyhaftowanym sercem - symbolem Najświętszego Serca Jezusowego.

Siostry od Wieczystej Adoracji - Zgromadzenie Sióstr Służebnic Ducha Świętego od Wieczystej Adoracji ${ }^{36}$; różowy habit, biały szkaplerz i welon.

słowa kluczowe: szkaplerz, habit, zakony męskie, zakony żeńskie

\section{BIBLIOGRAFIA}

Encyklopedja kościelna wyd. przez Michała Nowodworskiego, t. XXVII, Warszawa 1904, s. 518-522.

Encyklopedja powszechna, t. XXIV, nakład S. Orgelbranda, Warszawa 1867, s. 640-641.

Łoziński Bogumił, Leksykon zakonów w Polsce, Warszawa 1998.

Łoziński Bogumił, Konecki Krzysztof, Nasi księża, nasi zakonnicy, nasze siostry, Włoclawek 1999.

Marecki Józef, Zakony w Polsce, Kraków 2000.

Podręczna encyklopedya kościelna, red. Zygmunt Chełmicki, t. XXXVII-XXXVIII, Warszawa 1913, s. 376-382.

Wanat Benignus Józef, Zakon karmelitów bosych w Polsce, Kraków 1979, s. 21-26.

${ }^{34}$ Zgromadzenie do życia powołał w 1881 roku bł. Honorat Koźmiński.

${ }^{35}$ Zgromadzenie powołał do życia ks. Wiktor Braun w roku 1866. Siostry prowadzą działalność charytatywną i wychowawczą.

${ }^{36}$ Zgromadzenie powstało w Holandii w 1896 roku. W Polsce siostry mają swój klasztor w Nysie. 


\section{A MONASTIC SCAPULAR}

\section{Summary}

In the Benedictine rule, a monastic scapular was initially used as an apron protecting a habit during physical work. With the establishment of the Cistercians, it became an integral part of religious clothing. A scapular was adopted, among others, by the Benedictine monks and nuns, the Brothers Hospitallers of St John of God, the Dominican monks and nuns, the Camaldolese monks and nuns, the Capuchin Tertiaries, the Carmelite monks, the Carthusians, the Mercedarians, the Pauline Fathers, the Brothers Comforters of Gethsemane, the Congregation of the Sacred Hearts of Jesus and Mary, the Trinitarians, the Servite Order and the Albertine nuns, the Augustinian nuns, the Bernardine nuns, the Bridgettines, some Franciscan nuns, the Capuchin nuns, the Discalded Carmelite nuns, the Poor Clares, the Congregation of the Sisters of the Blessed Virgin Mary of Loreto, the Congregation of Sisters Shepherdesses of Divine Providence, The Piarist Sisters, the Congregation of the Nursing Sisters of Our Lady of Sorrows, the Congregation of the Handmaids of the Sacred Heart of Jesus.

Keywords: scapular, habit, male religious orders, female religious orders 